\title{
Colonialism, Postcolonialism, Neocolonialism: High-Time to Shift the Focus
}

\author{
A. K. Ivanova \\ V.N.Karazin Kharkiv National University, Kharkiv, Ukraine \\ Corresponding author. E-mail: a.k.ivanova6@gmail.com \\ Paper received 07.05.21; Accepted for publication 23.05.21
}

https://doi.org/10.31174/SEND-HS2021-254IX46-19

\begin{abstract}
The piece deals with the concepts of colonialism, postcolonialism, and neocolonialism as analytical frameworks for studying global world order within social sciences. The article stands on a critical position and aims to explain why the postcolonial approach is not relevant in its examination of the current world order. As an alternative the piece offers to consider a neocolonial framework as a more applicable approach to the analysis of the today's capitalist word order.
\end{abstract}

Keywords: colonialism, postcolonialism, neocolonialism, capitalism, imperialism.

Introduction. In the middle of the twentieth century, after the end of the Second World War, the global world order had radically changed: the centuries-old era of colonialism came to an end; the connections, relations, institutions, flows, and networks that were formed and supported by the major actors of international relations were collapsing. The character of global interactions had been gradually changing. The discursive environment was dominated by the rhetoric of economic growth and political equality, while in the political field, the national liberation movements of the old colonies had been becoming more noticeable. From the beginning of the 1950 s to the end of the 1970 s, the process of decolonization unfolded in most of the colonies. However, international equality has never become real but rather turned out to be only a manipulative discursive construct. Nevertheless, in response to the prevailing changes in the world order a new direction of interdisciplinary research has emerged within the social sciences - postcolonial studies, which focus on the research of the world after the era of colonialism. This field studies the impact of colonization on the non-Western world, draws attention to the lack of representation of non-Western experience and opens up the possibility to speak for those who have not had such an opportunity for a long time. Postcolonial theorists view the current global inequality system as a consequence of the centuries-old domination of some states over others, and therefore, as something residual, not as something unfolding at the present time. However, in the modern world, many relevant processes that are involved in the production of global inequality and could be characterized as colonial are still taking place. Accordingly, the postcolonial approach lacks sufficient methodology to describe the current processes of producing global inequality. This means that it is necessary to formulate a new theoretical and methodological framework that will more successfully cope with the description and explanation of the current state of global social order. A neocolonial approach can deal with such a task quite effectively.

Brief overview of related publications. The topic of colonialism and postcolonialism in the social sciences has been researched quite deeply, both theoretically, methodologically, and empirically. While the concept of neocolonialism, although originated in the middle of the 20th century, is still poorly developed. The author of the term is considered to be the Ghanaian philosopher and politician Kwame Nkrumah. In addition to him, both researchers working within the framework of the postcolonial tradition (Gayatri Chakravorty Spivak, Mark Langan, Edwin Charle) and researchers criticizing this approach (Boris Kagarlitsky, A. A. Gorelov, I. A. Bronnikov) turn to the concept of neocolonialism. These publications only create the foundation for further research of neocolonialism and point to vast, unexplored space within this field of knowledge.

Aim. The article aims at substantiating the need to develop a new approach to the study of the structure of the modern world order and explaining the outdatedness of the postcolonial approach to the study of the current processes of global inequalities construction. As an alternative, the paper proposes to pay more attention to the neocolonial approach to the analysis of the above-mentioned topic.

Materials and methods. The piece is of a theoretical and analytical nature; therefore, the main research methods include a theoretical analysis of the literature and a synthesis of several approaches in order to formulate the grounds for a new approach to the analysis of the global social order.

Results and discussion. The starting point in both approaches, postcolonial and neocolonial, is the concept of traditional colonialism. All further research is semantically and substantially built up upon it. Colonialism is recognized by both approaches as an empirical fact, while each of them views the state of the world order after the formal end of the colonial era in a different way. Therefore, this analysis should begin with the definition of the concept of colonialism.

Historically, colonialism is rooted in Ancient Greece and Rome. Back then this concept meant "the bringing of new territory into use by an expanding society, including settlements for trade and agriculture" [1, p.27]. However, in the form in which colonialism had existed from 1492 to the 1970 s, and in which it is studied within the social sciences, the concept is defined as "coercive incorporation into an expansionist state and individual distinction" [1, p.27]. Colonialism of this type is based on coercion, exploitation of all types of the resources, administrative and cultural work that helps establish hierarchies of power and delineate social and geographic boundaries around the world [1, p. 27-28]. Also, an important feature of classical colonialism is considered to be its formalized consolidation in legal documents, as well as in political and economic institutions. In addition, research on classical colonialism often focuses on the relationship between Europe and the three southern continents (Africa, 
Asia, and Latin America). European empires are regarded as the most influential - by 1914 they divided the whole world, turning the dependent territories into colonies [2, p. 72-76]. Colonies formed from the end of the 19th century, after the Franco-Prussian War, and up to the 1970s, belong to the capitalist type and are considered as the result of the onset of the era of the monopoly of finance capital [2, p.72-76]. Usually, the postcolonial approach focuses on examining the consequences of the existence of that particular stage of colonial relations that underlie the postcolonial world order.

Postcolonial studies as a scientific tradition and postcolonialism as a political movement formally date back to 1955 , when the Bandung Conference took place. During this event, the newly independent states of Asia and Africa declared non-alignment, proclaimed themselves as an independent power block representing political, economic, and cultural interests of the Third World [3, 17]. Postcolonial studies are based on a set of principles that indicate a large disparity in the development of former colonies and metropolises, which is still relevant after the end of colonial dependence. Postcolonial theorists propose a conceptual reorientation towards a greater representation of the non-Western world and knowledge produced outside the West. "Postcolonialism is about a changing world, a world that has been changed by struggle and which its practitioners intend to change further' [3, p. 7]. Moreover, from the point of view of Robert J. Young and his proponents, postcolonialism equals tricontinentialism, which means that the central focus of the postcolonial approach is on three continents - Asia, Africa, and Latin America - which are subordinate to Europe and North America, and are in the position of economic inequality [young 4]. The postcolonial approach may seem to have great emancipatory potential and to seek for better representation of the non-Western world, but there are reasons to believe that it itself generates a number of injustices and denies equal representation of certain underrepresented groups.

As noted by Boris Kagarlitsky [4], the process of decolonization at the end of the twentieth century did not take place under the auspices of national liberation movements, as proponents of the postcolonial approach claim. Decolonization initially followed the imperialist scenario and aggravated dependence on the center [4, p.633-635]. Large capitalist countries, former metropolises, and new leaders were forced to adapt to the changing post-war world when the costs of maintaining colonies became higher than the benefits. Thus, decolonization and the subsequent neocolonial form of dependence became the simplest and most conservative solution, in which the metropolises lost their special political sovereignty, but retained the economic status quo. "National independence and decolonization not only did not weaken the position of imperialism as a system but, on the contrary, breathed new life into the peripheral capitalism, which was in crisis" [4, p.638]. That is why at the end of the twentieth century, the real liberation of the colonies from the dependence of the metropolises was impossible: developed capitalist states and large corporations, which by the end of the century become new subjects of international relations, changing the structure of capitalism, were forced to constantly subjugate more and more spaces. This, contrary to the basic principles of postcolonialism, indicates that colonial dependence has not ended, but has taken on a new form.

Kwame Nkrumah, who introduced the concept of neoco- lonialism, defined it as "modern attempts to perpetuate colonialism while at the same time talking about "freedom"" [5]. For him, neocolonialism is the last stage of imperialism, which is characterized by its invisibility and nonformalization. It is distinguished not by the elimination of colonial dependence, but, on the contrary, by deepening of exploitation in all domains (economic, political, cultural, ideological). Gayatri Chakravorty Spivak, who originates from colonial India, also uses the concept of neocolonialism. With its help, she describes a new stage of colonialism, more economic, but less territorial: “... in fact neocolonialism is like radiation - you feel it less like you don't feel it - you feel it like you're independent" [6, p. 221]. Thus, she agrees with Kwame Nkrumah that neocolonialism is less visible and tangible, but no less coercive. At the same time, unlike K. Nkrumah and the theorists of postcolonialism, G. Spivak expresses an important for the neocolonial approach idea that neocolonialism is a kind of metanarrative that describes the disparity not only between the West and the former colonies but also includes relations between other countries, which were not colonial before [6, p. 223].

This is an important thesis for identifying the relationship between neocolonialism and capitalism since the former is the product and the instrument of the latter. A constant expansiveness, which forces capitalism to continually explore new territories, lies in its nature [7]. Capitalism as a global world order builds neocolonial relations in the former colonies and is also moving to new spaces that were not previously dependent on the metropolises. For example, dozens of states appeared with the collapse of the Soviet Union and the Socialist bloc. Thus, capitalistically developed countries got a chance to extend their influence and build neocolonial relations with the new states. Postcolonial theorists exclude these countries from the scope of their research and do not view them as experiencing colonial exploitation. Postcolonialism mainly deals with the problems of the non-white population. However, it is actually not the color of the skin, but the relations towards the capital that define the amount of power and visibility people, social groups and the whole nation-states have. Postcolonial studies focus on the population of ex-colonies which is normally non-western in terms of culture and geography, non-white in terms of skin color, but overlooks a whole layer of countries (beyond the area of tricontinentialism) that today turn into colonies and social groups that became exploited.

The same applies to the subjects of the dominant pole of neocolonial relations. If postcolonialism deals with the relationship between The West and The Rest [8] and challenges western ways of seeing things and producing knowledge, then it overlooks new centers of exploitation, which are also determined not geographically but by their relation towards capital. Thus, within the framework of the neocolonial approach, China, a large non-Western state, declaratively socialist but gradually implementing elements of market economy, is viewed as a new "metropolis", which is no less than Western countries involved in the processes of exploitation and spreads its influence beyond state borders [9]. From this, we can conclude that colonialism today is more associated with capitalism and the market economy than with the concept of the West.

Another area of under-representation within the postcolonial approach concerns research subjects. The main representatives of the postcolonial approach are researchers from 
former colonies or, to a lesser extent, from metropolises. "New colonies" don't have a voice within this framework or within any other. So, the neocolonial approach might become the one to give a voice to any state exploited by capitalist countries, international organizations, transnational corporations, and other agents of capitalist expansion. Since the post-socialist space became the main field of capitalist expansion starting from the late 80th, many new countries have got into a trap of colonial relations. This space has no collective experience of colonialism in the past but is for sure experiencing it now. Researchers from these countries rarely define them as neocolonial, but rather view them as postSoviet. Although the Soviet past undoubtedly determines the present, there are many relevant processes happening in the present time that affect the nature of the domestic and foreign policies of these countries, their place in the global hierarchy of power. In this perspective, the neocolonial approach provides much more possibilities than the post-Soviet or the postcolonial ones do.

In addition, the word "postcolonialism" morphologically includes the prefix "post-", which lexically means "arising after something" and indicates, on the one hand, secondariness and dependence, and on the other, rootedness in the past. So, on the semantic level, postcolonialism deals with the world after colonialism and excludes new forms of colonial dependence from the analytical scope. Perhaps this approach was relevant at the time of its inception, but today, 70 years later, we understand quite clearly that colonial dependence has not disappeared, and there is no world after colonialism. The new types of colonial dependence differ from the classical ones only formally, which does not make them juster.

Just as at the ideological level in the late 70s, Western capitalism gave birth to neoliberalism in order to ensure the legitimacy of its own existence, so on the practical level does it turned into neocolonial practices that support and ensure its expansion into new spaces (and not only geographic ones). Therefore, today we can conclude that the capitalist world order is rather neocolonial in nature, and the postcolonial approach could be quite misleading and does not cover the entire spectrum of global inequalities that this order gener- ates.

Conclusion. Historically, the era of postcolonialism begins in 1955. At that time, postcolonialism was becoming an actual conceptual framework for describing global processes. Both academically and politically, postcolonialism was a protest alternative to Western domination. Thanks to the postcolonial movement, those objects of research that previously could not be studied at all were included in the academic agenda: local identity, national liberation movements, the dominance of Western discourse and culture, issues of representation of colonized groups, etc. In addition, researchers from colonized countries received the possibility of representation within the scientific field. But today, almost 70 years later, the global social order has changed both in form and in substance. A new conceptual framework is needed to describe it properly. And, perhaps, the neocolonial approach today will be more relevant for the study of the system of global inequalities.

Robert Young, explaining the consequences of the postcolonial movement, says that before its emergence, the world was bipolar, divided between the USA and the USSR [3, p.16]. Decolonization gave birth to a tripolar world (countries of the First, Second, and Third Worlds), which in turn became the object of research in postcolonial theory. Today, as Thomas Piketty notes [10], the gap between rich and poor states is critically growing, which means that there is practically no room left for the Second World. The world is striving for bipolarity again. However, this time the division is not based on ideology, but rather on the attitude towards the capital, which determines the place of the state in the world hierarchy. This capitalist hierarchy is supported by neocolonial practices that, in one way or another, affect the whole world and conquer new territories. Modern processes of constructing global inequality are systemic in nature and cover the whole world. Therefore, limiting one's research only to former colonies, as the supporters of the postcolonial approach suggest, means deliberately excluding from it a whole layer of societies that are located within the same hierarchy. To study these processes, a new conceptual framework is needed that will embrace the whole world. Neocolonial approach could be a productive alternative.

\section{ЛИТЕРАТУРА}

1. Cooper, Frederick. Colonialism in Question: Theory, Knowledge, $\quad$ 6. Spivak, Gayatri Chakravorty, and Robert Young. "NeocolonialHistory. Berkeley; Los Angeles; London: University of California Press, 2005.

2. Ленин В.И. Империализм как высшая стадия капитализма / Ленин Владимир Ильич. - Москва: Издательство политической литературы, 1978. - 135 с.

3. Young, Robert J. Postcolonialism: A Very Short Introduction, Oxford; New York: Oxford University Press, 2003.

4. Кагарлицкий Б.Ю. От империй - к империализму. Государство и возникновение буржуазной цивилизации / Гос. ун-т - Высшая школа экономики. - М.: Изд. дом Гос. ун-та Высшей школы экономики, 2010.

5. Nkrumah, Kwame. Neo-Colonialism, the Last Stage of Imperialism. $1965 . \quad$ Access at: https://www.marxists.org/subject/africa/nkrumah/neocolonialism/introduction.htm ism and the Secret Agent of Knowledge." Oxford Literary Review, vol. 13 , no. $1 / 2,1991$, pp. 220-251.

7. Harvey, David. New Imperialism, Oxford University Press, New York, $2003-263 \mathrm{p}$.

8. Hall S. The West and The Rest/ Stuart Hall// in Understanding Modern Societies, Book 1: Formations of Modernity, edit. by Stuart Hall, Bram Gieben, Cambridge: Polity Press, 1992 - pp. 275-333.

9. Balasubramanyam, VN 2015, 'China and India's Economic Relations with African Countries- Neo-Colonialism Eastern Style?', Journal of Chinese Economic and Business Studies, vol. 13, no. 1, pp. 17-31.

10. Piketty, Thomas. Capital in the Twenty-First Century. Harvard University Press, 2014.

\section{REFERENCES}

2. Lenin, V.I. Imperialism, the Highest Stage of Capitalism / Lenin Vladimir Ilyich. - Moscow: Political Literature Publishing, 1978. - 135 p.

4. Kagarlitsky B. U. From Empire to Imperialism. State and The

Emergence of a Bourgeoisie Civilization / State University Higher School of Economics. - Moscow: Publishing House of the State University — Higher School of Economics, 2010-680p. 